\title{
On the creeping increase of vessels' fishing power
}

\author{
Maria L. D. Palomares ${ }^{1}$ and Daniel Pauly ${ }^{1}$
}

\begin{abstract}
This contribution presents a synthesis, via a semilogarithmic regression, of estimates of the slow increase of technological efficiency, or "creep factor," as estimated by various authors for a number of demersal and pelagic fisheries. This factor is used in fisheries science to adjust for the gradual increase in the effectiveness of fishing gear resulting from the successive introduction of technological improvement to fishing gear and vessels. Altogether, 51 estimates of this creep factor, mostly around $2-4 \% / y r$ and covering periods from 4 to $129 \mathrm{yr}$, were assembled or newly calculated from secondary data and shown to decrease as the period covered increased. This finding is compatible with the hypothesis that creep factors are usually estimated and published to correct for the introduction of an effective new technology over a short period of time. We suggest that estimates obtained in this fashion cannot be applied to long-term analyses and propose instead our empirical relationship, derived from estimates of creep factor and the number of years covered in a study. Also, our study confirms that technology creep must be included in all analyses involving time series of fishing effort, particularly if they exceed one decade in temporal coverage.
\end{abstract}

Key Words: effectiveness of fishing gear; fishing power; technological efficiency; technology creep factor

\section{INTRODUCTION}

People have been fishing for millennia and they have always tried to improve their methods (von Brandt 1964), both to increase their catch and to compensate for the declining catch per unit effort (CPUE) due to diminishing abundance of the underlying resources that fishing causes (Engelhard 2016). Since the late 19th century, following the introduction of steam trawlers in England, which marks the start of industrialized fishing, the improvement of technology has been relentless; the current vessels are much more powerful than steam vessels of similar tonnage (Engelhard 2008, Thurstan et al. 2010, Engelhard 2016).

The relationship between fishing mortality and fishing effort is $F$ $=f \times q$, where $F$ is the fraction of the fish population that dies from fishing during a unit of time (conventionally one year); $f$ is a measure of fishing effort (e.g., boats/d or fishing-h/d of a certain type of fishing vessel); and $q$ is the catchability coefficient (Beverton and Holt 1957, Arreguín-Sánchez 1996).

Technological creep $(C)$ can be conceived as either a dimensionless change in catchability $(q)$ or a dimensionless change in some aspect of nominal effort (Gulland 1956, Sanders and Morgan 1976). Either way, it affects fishing mortality. Conversely, if $F$ is to be kept at a given level, effective effort will increase due to technological creep, and nominal effort must be reduced accordingly.

Technological improvement can be conceptually separated into two groups: (1) major improvements in gear design, fish finding, and catch handling resulting in massive increase in effective fishing effort when they are implemented throughout a fleet within a few years; and (2) small background alterations in the rigging of a vessel or the skill of skippers at handling new technology or applying information technology, etc. (see Marchal et al. 2006). Technology creep factors receive far too little attention from fisheries scientists and even less from fisheries managers, for example, when they attempt to freeze the amount of fishing effort at a certain level but fail to account for the increase in effective effort of the vessels whose number is frozen. A similar problem occurs when subsidizing fleet retirement programs that allow decommissioning funds to be applied for the purchase of new, more efficient vessels (Munro and Sumaila 2002 and references therein,
Pauly et al. 2002). Most studies of the creep factor refer to cases of the first type because the effect is strong and visible and thus justifiably attracts scientific and management attention. However, because of the cumulative effect, the changes of the second type are also important; they occur relentlessly, even when no major technology improvements appear to be taking place.

Engelhard (2016) emphasizes the general lack of quantitative information allowing for the estimation of the speed at which changes in fishing power happen over time and encourages more research on the topic. Our contribution's aims, therefore, are to present a number of estimates of this creep factor (both previously published and newly estimated) and, based on those, to propose an empirical relationship derived to allow inferences on long-term values of creep factor by combining both types of technologial improvements (Fig. 1).

Fig. 1. Simulated increase in effective effort over a 50 -yr period comprising a mixture of background rates ( $\%$ technological creep $=1$ and $2 \%$ ) and rapid increases $(5 \%)$ due to technological improvements. The average rate of technological creep $(2.41 \%$; dotted line) is obtained by comparison of the beginning and end estimates of effective effort but can be approximated by an average rate of increase weighted by the number of years $(2.42 \%)$.

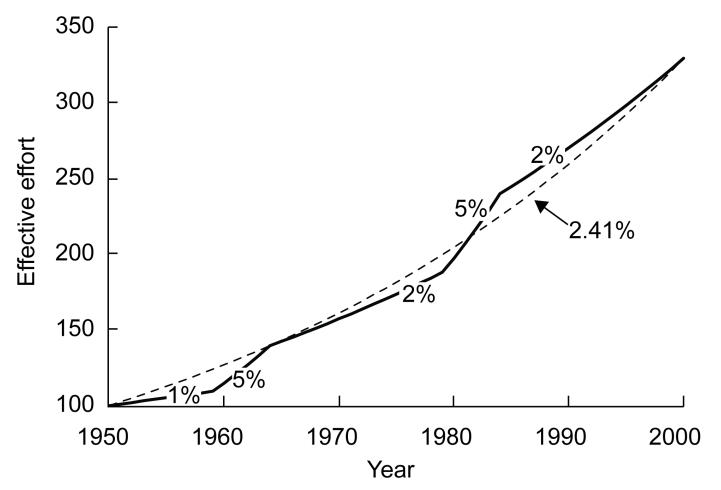




\section{MATERIALS AND METHODS}

A literature search to update the data of Pauly and Palomares (2010) was conducted (originally in 2013 and updated in 2017), targeting estimates of time series trends of fishing power or fishing efficiency available from online resources. We searched the Aquatic Sciences and Fisheries Abstracts (ASFA), Web of Science (WS), and Google Scholar (GS) using the search terms "fishing power" and "fishing efficiency" occurring in the title. This search yielded 127, 45, and 155 hits for fishing power and 127, 31, and 133 hits for fishing efficiency in ASFA, WS, and GS, respectively. Of these records, 24 contributions contained usable time series data of fishing power (51 case studies; see Table 1) from which estimates of the annual increase of fishing power or fishing efficiency were obtained.

Though straighforward, the methods used to transform the source data to percentage annual increase in fishing power $(\mathrm{C} \%)$ differed because the source data were heterogeneously expressed as: annual rate of change (Ward 2008), annual compounding increase (Hannesson et al. 2008, Thorson and Berkson 2010), average increase in fishing power (Brown et al. 1995, Zhou et al. 2015), fishing power in smack units (Engelhard 2008), increase in catchability coefficient (Atmaja and Nugroho 2011), change in technology coefficient (Gelchu and Pauly 2007) or efficiency (Hutton et al. 2003), change in loading capacity (Ruiz-Luna et al. 1997), average trend in fishing power (Marchal et al. 2002), or chain of total factor productivity (Squires 1994). Details of these transformations are provided in Table 1. In cases for which the source data were from comparisons of fishing power or efficiency from different vessel types fishing in parallel, the instantaneous rate of technological creep $\left(C ; \mathrm{yr}^{-1}\right)$ was obtained, and the corresponding annual percentage increase $(C \%)$ is reported (Table 1) along with the resulting regression statistics (see Gascuel et al. 1993, Gelchu and Pauly 2007, Engelhard 2008).

\section{RESULTS}

The first result we obtained is a series of 51 estimates of $C$ (Table 1). We first comment in detail on two sets of these estimates. We then continue with their analysis.

Our first case, based on portions of the data in Table 1, presents estimates of $C$ (Fig. 1) in English trawl fisheries for cod and plaice based on the classical method for fishing power estimates (Gulland 1956) for trawlers fishing in parallel. This time series, extending from 1880 to 2005, was reported by Engelhard (2008: table 1). Here, all ranges were replaced by the corresponding midranges, and a few points were identified as outliers (e.g., those representing sailing vessels; see Fig. 2). The resulting slopes of the plot (Fig. 2, Table 1) provide relatively low estimates of $C$ for cod and plaice, respectively, pertaining to an extraordinarily long time series of $129 \mathrm{yr}$.

Our second case is the result of an informal workshop reported by Fitzpatrick (1996; see Table 2), whose main result was that, over a period of $30 \mathrm{yr}$, the participating skippers of a wide range of vessel types perceived an increase in the efficiency of fishing gear, i.e., fishing power, equivalent to $C \%=4.43 \% / \mathrm{yr} \pm 0.00255$. Details of this exercise are not available, which would enable the results from the different fisheries included therein to be discussed separately. Thus, the entire exercise contributed only one estimate to our analysis (Table 1, Fig. 3).
Fig. 2. Increase in fishing power of English demersal trawl fisheries for cod (top) and plaice (bottom) based on data from Engelhard (2008:table 1).

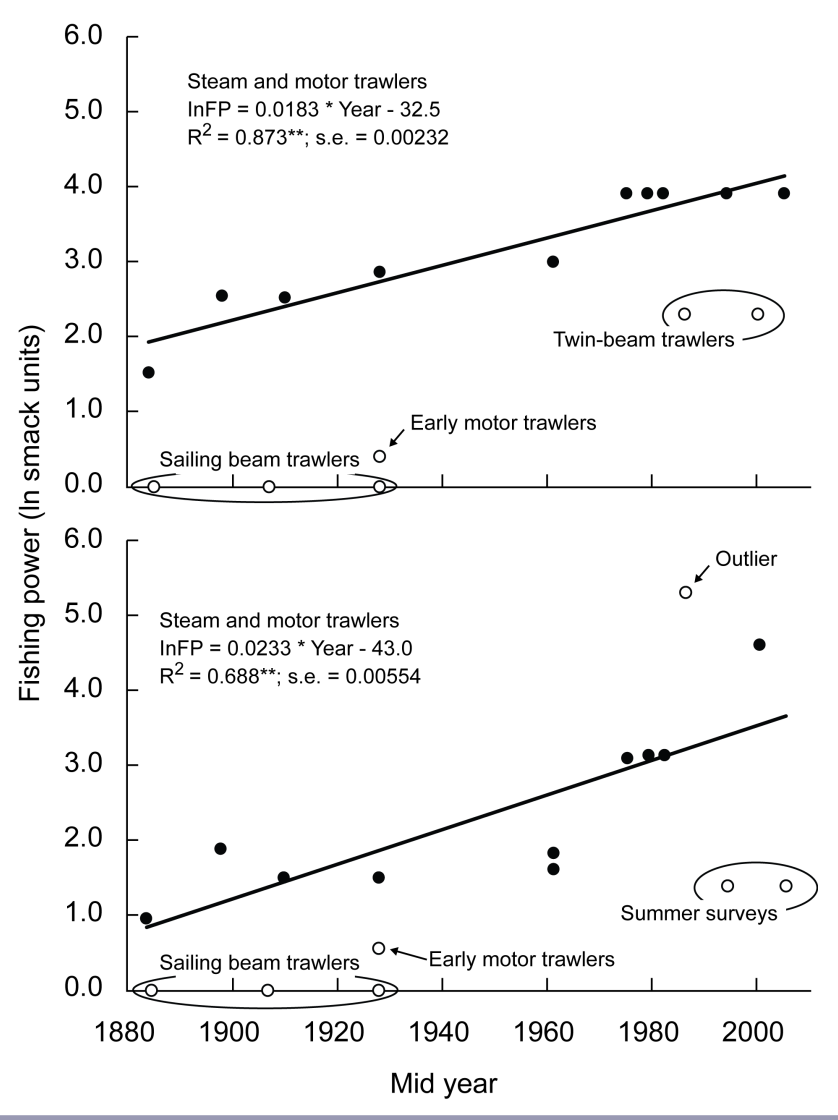

Fig. 3. Relationship between technological creep and the period to which the estimate applies. $C \%=$ percent change in technological creep per year; $\ln (C \%)=2.625-0.511 \times \ln ($ Year $)$ $\left(\mathrm{r}^{2}=0.153, \mathrm{r}=-0.3906, \mathrm{df}=49, P<0.0046\right)$. The $\mathrm{X}$ on the regression line indicates an average fishing power increase of $3.4 \%$ for the average period of $15 \mathrm{yr}$; dashed lines indicate the $95 \%$ confidence limits.

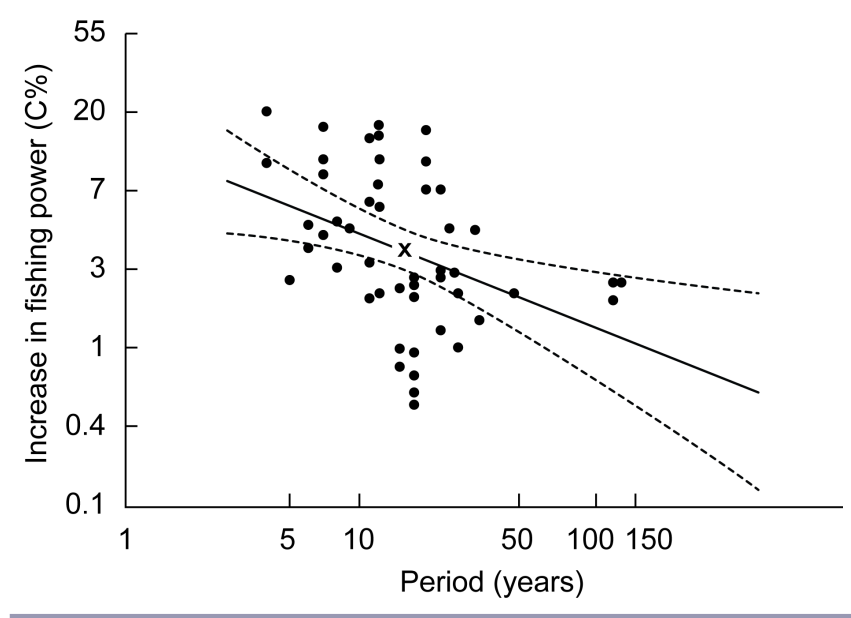


Table 1. Technological creep estimates for various fisheries and periods. $C=$ technological creep; $\mathrm{CPUE}=\mathrm{catch}$ per unit effort, $\mathrm{FP}=$ fishing power, GPS = global position system, IFP = index of fishing power, TC = technology coefficient, TFP $=$ Tornqvist index of total factor productivity.

\begin{tabular}{|c|c|c|c|c|c|}
\hline $\begin{array}{l}\text { Nu- } \\
\text { mber }\end{array}$ & Fishery or species & Years & $C\left(\mathrm{yr}^{-1}\right)$ & $\begin{array}{l}\text { Standard error } \\
\text { of } C\end{array}$ & Estimation method and source \\
\hline 1 & $\begin{array}{l}\text { Lofoten cod (Gadus morhua) } \\
\text { fishery }\end{array}$ & $1860-1988$ & 0.0233 & 0.0426 & $\begin{array}{l}\text { Based on } 2.3 \% \text { annual compounding increase estimated by } \\
\text { Hannesson et al. (2008:table } 4)\end{array}$ \\
\hline 2 & $\begin{array}{l}\text { British North Sea Atlantic cod } \\
\text { trawl fishery }\end{array}$ & $1886-2005$ & 0.0183 & 0.00232 & $\begin{array}{l}\text { Change in FP (smack units); based on data from Engelhard } \\
(2008: \text { table 1) with } \ln (\mathrm{FP})=0.0183 \times \text { Year }-32.5 \text { (Fig. } 2)\end{array}$ \\
\hline 3 & $\begin{array}{l}\text { British North Sea European plaice } \\
\text { (Pleuronectes platessa) trawling }\end{array}$ & $1886-2005$ & 0.0233 & 0.00554 & $\begin{array}{l}\text { FP (smack units); based on data from Engelhard (2008:table 1) } \\
\left.\text { with } \ln (\mathrm{FP})=0.0233 \times \text { Year }-43.0, \mathrm{r}^{2}=0.688^{* *}, \mathrm{df}=8 \text { (Fig. } 2\right)\end{array}$ \\
\hline 4 & $\begin{array}{l}\text { Japan distant-water pelagic long } \\
\text { liners }\end{array}$ & $1954-1998$ & 0.02 & 0.0155 & $\begin{array}{l}\text { Annual mean rate of change for mako shark, blue marlin, and } \\
\text { bigeye, yellowfin, and skipjack tunas; based on Ward (2008: } \\
\text { table 2) }\end{array}$ \\
\hline 5 & $\begin{array}{l}\text { Java Sea purse seine fishery for } \\
\text { small pelagic fishes }\end{array}$ & $1976-2007$ & 0.0143 & N/A & $\begin{array}{l}\text { Based on Atmaja and Nugroho (2011) estimating an increase of } \\
58 \% \text { of the } 2007 \text { catchability coefficient from the } 1976 \\
\text { coefficient }\end{array}$ \\
\hline 6 & $\begin{array}{l}\text { Wide range of vessel types (Table } \\
\text { 2) }\end{array}$ & $1965-1995$ & 0.0443 & 0.00255 & $\begin{array}{l}\text { Change in TC; based on data from Gelchu and Pauly }(2007 \text { : } \\
\text { table } 2.5) \text { based on Fitzpatrick }(1996 \text {; see Table } 2) \text { with } \ln (\mathrm{TC})= \\
0.0443 \times \text { Year }-87.7, \mathrm{r}^{2}=0.893^{* *}, \mathrm{df}=36\end{array}$ \\
\hline 7 & $\begin{array}{l}\text { Australian silver-lipped pearl } \\
\text { oyster (Pinctada maxima); GPS- } \\
\text { aided fishery }\end{array}$ & 1984-2009 & 0.0101 & N/A & $\begin{array}{l}\text { Based on Hart et al. (2011) estimating an increase of FP by } 30 \% \\
\text { due to the introduction of GPS }\end{array}$ \\
\hline 8 & Gulf of Mexico fisheries & $1981-2006$ & 0.02 & N/A & $\begin{array}{l}\text { Based on Thorson and Berkson (2010:table } 4) \text { for gag grouper } \\
\text { (Mycteroperca microlepis), red grouper (Epinephelus morio), red } \\
\text { snapper (Lutjanus campechanus), mutton snapper (L. analis), } \\
\text { king mackerel (Scomberomorus cavalla), and greater amberjack } \\
\text { (Seriola dumerili) fisheries }\end{array}$ \\
\hline 9 & Australian northern prawn fishery & $1987-2011$ & 0.026 & N/A & $\begin{array}{l}\text { Based on average FP increase of } 2.6 \% \text { estimated by Zhou et al. } \\
\text { (2015) for banana prawn (Fenneropenaeus merguiensis) }\end{array}$ \\
\hline 10 & $\begin{array}{l}\text { Pacific ocean perch (Sebastes } \\
\text { alutus) trawl fishery, Vancouver } \\
\text { Island, Canada }\end{array}$ & $1953-1976$ & 0.0458 & N/A & Based on $2 \%$ increase reported by Kimura (1981) \\
\hline 11 & $\begin{array}{l}\text { Thread herring (Opisthonema } \\
\text { spp.) fishery, Sinaloa, Mexico }\end{array}$ & $1972-1993$ & 0.0737 & 0.0125 & $\begin{array}{l}\text { IFP based on data from Ruiz-Luna et al. }(1997: \text { table } 1 ; \text { CPUE }= \\
\left.a \times[\text { loading capacity }]^{b}\right) ; \text { result was } \ln (\mathrm{FP})=0.0737 \times \text { Year }- \\
0.786, \mathrm{r}^{2}=0.684^{* *}, \mathrm{df}=16\end{array}$ \\
\hline 12 & $\begin{array}{l}\text { Western rock lobster (Panulirus } \\
\text { cygnus) shallow waters, Western } \\
\text { Australia }\end{array}$ & $1971-1992$ & 0.0125 & N/A & Mean of FP increase: 0.005-0.02; Brown et al. (1995) \\
\hline 13 & $\begin{array}{l}\text { Western rock lobster deep waters, } \\
\text { Western Australia }\end{array}$ & $1971-1992$ & 0.025 & N/A & Mean of FP increase: $0.01-0.04$; Brown et al. (1995) \\
\hline 14 & $\begin{array}{l}\text { Pacific cod (Gadus macrocephalus) } \\
\text { Butterwort ground fishery, } \\
\text { Canada }\end{array}$ & $1960-1981$ & 0.0271 & 0.009649 & $\begin{array}{l}\text { FP increase based on data from Westrheim and Foucher }(1985 \text { : } \\
\text { table 6), with } \ln (\mathrm{FP})=0.0271 \times \text { Year }-53.0, \mathrm{r}^{2}=0.282^{*}, \mathrm{df}= \\
20\end{array}$ \\
\hline 15 & $\begin{array}{l}\text { Norwegian gillnet fishery, North } \\
\text { Sea }\end{array}$ & $1980-1998$ & 0.075 & 0.0457 & $\begin{array}{l}\text { Mean trend in IFPs for cod, haddock, and saithe; based on data } \\
\text { from Marchal et al. (2002:table 6) }\end{array}$ \\
\hline 16 & $\begin{array}{l}\text { Norwegian longline fishery, North } \\
\text { Sea }\end{array}$ & $1980-1998$ & 0.16 & 0.01 & $\begin{array}{l}\text { Mean trend in IFPs for cod, haddock, and saithe; based on data } \\
\text { from Marchal et al. (2002:table 6) }\end{array}$ \\
\hline 17 & $\begin{array}{l}\text { Norwegian otter trawl fishery, } \\
\text { North Sea }\end{array}$ & $1980-1998$ & 0.106 & 0.0438 & $\begin{array}{l}\text { Mean trend in IFPs for cod, haddock, and saithe; based on data } \\
\text { from Marchal et al. (2002:table 6) }\end{array}$ \\
\hline 18 & $\begin{array}{l}\text { Norwegian bottom trawl cod } \\
\text { fishery, Barents Sea }\end{array}$ & $1971-1985$ & 0.0214 & 0.2189 & $\begin{array}{l}\text { Based on Skjold et al., unpublished manuscript: } \underline{\text { http://ices.dk/ }} \\
\text { sites/pub/CM\%20 } \\
\text { Doccuments/1996/P/1996 P3.pdf }\end{array}$ \\
\hline 19 & European fisheries & 1985-1999 & 0.01 & N/A & TC; Banks et al. (2001) and Kirkley et al. (2001) \\
\hline 20 & Greek bottom trawl fishery & 1994-2008 & 0.00791 & N/A & $\begin{array}{l}\text { Annual } C \text { estimated by Damalas et al. (2014:table } 3 \text { ) for hakes, } \\
\text { mullets, shrimps, squids, and sharks }\end{array}$ \\
\hline 21 & $\begin{array}{l}\text { Danish cod gillnet fishery, Baltic } \\
\text { Sea }\end{array}$ & $1987-1998$ & 0.06 & N/A & Increase of IFP; Marchal et al. (2001:table 3) \\
\hline 22 & $\begin{array}{l}\text { Danish cod trawl fishery, Baltic } \\
\text { Sea }\end{array}$ & $1987-1998$ & 0.02 & N/A & Increase of IFP; Marchal et al. (2001:table 3) \\
\hline 23 & Danish gillnet fishery, North Sea & $1987-1998$ & 0.147 & 0.0788 & $\begin{array}{l}\text { Mean trend in IFPs for cod, plaice, and sole; based on data } \\
\text { from Marchal et al. (2002:table 6) }\end{array}$ \\
\hline 24 & $\begin{array}{l}\text { Danish otter trawl fishery, North } \\
\text { Sea }\end{array}$ & $1987-1998$ & 0.08 & 0.04 & $\begin{array}{l}\text { Mean trend in IFPs for cod and plaice; based on data in } \\
\text { Marchal et al. (2002:table 6) }\end{array}$ \\
\hline
\end{tabular}




\begin{tabular}{|c|c|c|c|c|c|}
\hline 25 & Danish seine fishery, North Sea & $1987-1998$ & 0.11 & 0.02 & $\begin{array}{l}\text { Mean trend in IFPs for cod and plaice; based on data in } \\
\text { Marchal et al. (2002:table 6) }\end{array}$ \\
\hline 26 & $\begin{array}{l}\text { Hake (Merluccius merluccius) } \\
\text { fixed net fishery }\end{array}$ & $1986-1997$ & 0.06 & N/A & Mean rate of change in FP; Morizur and Carn (2000) \\
\hline 27 & $\begin{array}{l}\text { French sole (Solea vulgaris, } \\
\text { Soleidae) fixed net fishery }\end{array}$ & $1986-1997$ & 0.17 & N/A & Annual rate of change in FP; Morizur and Carn (2000) \\
\hline 28 & $\begin{array}{l}\text { French-Ivoirian-Senegalese } \\
\text { yellowfin tuna (Thunnus albacares) } \\
\text { fishery }\end{array}$ & $1980-1990$ & 0.1416 & 0.0334 & $\begin{array}{l}\text { FP; based on data from Gascuel et al. (1993:fig. 5a) with } \ln (\mathrm{FP}) \\
=0.1416 \times \text { Year }-12, \mathrm{r}^{2}=0.666^{* *}, \mathrm{df}=9\end{array}$ \\
\hline 29 & $\begin{array}{l}\text { Spanish purse seine yellowfin tuna } \\
\text { fishery; Eastern Atlantic }\end{array}$ & $1980-1990$ & 0.0636 & 0.0178 & $\begin{array}{l}\text { FP; based on data from Gascuel et al. }(1993 \text { :fig. } 5 b) \text { with } \ln (\mathrm{FP}) \\
=0.0636 \times \text { Year }-5.746, \mathrm{r}^{2}=0.586^{* *}, \mathrm{df}=9\end{array}$ \\
\hline 30 & $\begin{array}{l}\text { Torres Strait tiger prawn trawl } \\
\text { fishery }\end{array}$ & $1989-1999$ & 0.01872 & N/A & FP increase; O’Neill et al. (2003:table 3) \\
\hline 31 & North Sea English fleets & $1990-2000$ & 0.0297 & N/A & $\begin{array}{l}\text { Estimated annual technological efficiency increase by Hutton et } \\
\text { al. }(2003) \text { for otter trawl (IFP }=0.005) \text {, pot }(\text { IFP }=0.024) \text {, and } \\
\text { Nephrops }(\text { IFP }=0.06 \text { ) fleets }\end{array}$ \\
\hline 32 & $\begin{array}{l}\text { Pacific Coast ground fish trawl } \\
\text { fishery }\end{array}$ & $1981-1989$ & 0.0460 & 0.0139 & $\begin{array}{l}\text { TFP; based on data in Squires }(1994 \text { :table } 3) \text { with } \ln (\text { TFP })= \\
0.0460 \times \text { Year }-91.3, \mathrm{r}^{2}=0.610^{*}, \mathrm{df}=7\end{array}$ \\
\hline 33 & $\begin{array}{l}\text { Dutch beam trawl fishery, North } \\
\text { Sea }\end{array}$ & $1991-1998$ & 0.05 & 0.0785 & $\begin{array}{l}\text { Mean trend in IFPs for cod, plaice, and sole; based on data } \\
\text { from Marchal et al. (2002:table 6) }\end{array}$ \\
\hline 34 & $\begin{array}{l}\text { Pacific Coast ground fish trawl } \\
\text { fishery }\end{array}$ & $1982-1989$ & 0.0279 & N/A & TFP; Squires (1994:table 1) \\
\hline 35 & $\begin{array}{l}\text { French spider crab (Maja } \\
\text { squinado) fixed net fishery }\end{array}$ & $1992-1998$ & 0.11 & N/A & Mean rate of increase; Morizur and Carn (2000) \\
\hline 36 & $\begin{array}{l}\text { Western rock lobster fishery, } \\
\text { Australia }\end{array}$ & $1983-1989$ & 0.165 & 0.0512 & $\begin{array}{l}\text { Catch rate increase by period, testing four technology factors } \\
\text { for legal-size lobsters; Fernandez et al. (1997:table } 2)\end{array}$ \\
\hline 37 & Faeroese haddock longline fishery & $1996-2002$ & 0.09 & N/A & Annual FP increase estimated by Eigaard et al. (2011) \\
\hline 38 & Faeroese cod longline fishery & $1996-2002$ & 0.043 & N/A & Annual FP increase estimated by Eigaard et al. (2011) \\
\hline 39 & $\begin{array}{l}\text { UK English Channel otter trawler } \\
\text { fleet }\end{array}$ & $1993-1998$ & 0.048 & N/A & Annual FP increase estimated by Pascoe et al. (2003) \\
\hline 40 & UK English Channel pot fleet & 1993-1998 & 0.036 & N/A & Annual FP increase estimated by Pascoe et al. (2003) \\
\hline 41 & $\begin{array}{l}\text { Australian northern prawn } \\
\text { (Penaeus esculentus, } P \text {. } \\
\text { semisulcatus) fishery }\end{array}$ & $1988-1992$ & 0.0235 & 0.00230 & $\begin{array}{l}\text { Annual estimates of FP; based on data from Robins et al. (1998: } \\
\text { fig. 3), with } \ln (\mathrm{FP})=0.02352 \times \text { Year }-46.75, \mathrm{r}^{2}=0.972^{* *}, \mathrm{df}= \\
3\end{array}$ \\
\hline 42 & $\begin{array}{l}\text { Western rock lobster fishery, } \\
\text { Australia }\end{array}$ & $1989-1992$ & 0.105 & 0.0298 & $\begin{array}{l}\text { Catch rate increase by period, testing four technology factors } \\
\text { for legal-size lobsters; Fernandez et al. (1997:table 2) }\end{array}$ \\
\hline 43 & $\begin{array}{l}\text { Brixham demersal trawl fishery, } \\
\text { UK }\end{array}$ & $1965-1968$ & 0.201 & N/A & Annual change in FP; Houghton (1977) \\
\hline 44 & $\begin{array}{l}\text { Eastern king prawn (Melicertus } \\
\text { plebejus) trawl fishery (all depths), } \\
\text { Queensland, Australia }\end{array}$ & $1988-2004$ & 0.0225 & 0.00154 & $\begin{array}{l}\text { Annual change in FP; based on O'Neill and Leigh (2007:table 2) } \\
\text { with } \ln (\mathrm{FP})=0.02249 \times \text { Year }-44.73, \mathrm{r}^{2}=0.934^{* *}, \mathrm{df}=15\end{array}$ \\
\hline 45 & $\begin{array}{l}\text { Eastern king prawn (shallow) } \\
\text { trawl fishery, Queensland, } \\
\text { Australia }\end{array}$ & $1988-2004$ & 0.0245 & 0.00130 & $\begin{array}{l}\text { Annual change in FP; based on O'Neill and Leigh (2007:table } 2) \\
\text { with } \ln (\mathrm{FP})=0.02452 \times \text { Year }-48.75, \mathrm{r}^{2}=0.960^{* *}, \mathrm{df}=15\end{array}$ \\
\hline 46 & $\begin{array}{l}\text { Eastern king prawn (deep) trawl } \\
\text { fishery, Queensland, Australia }\end{array}$ & $1988-2004$ & 0.0195 & 0.00261 & $\begin{array}{l}\text { Annual change in FP; based on O'Neill and Leigh (2007:table 2) } \\
\text { with } \ln (\mathrm{FP})=0.01948 \times \text { Year }-38.79, \mathrm{r}^{2}=0.789^{* *}, \mathrm{df}=15\end{array}$ \\
\hline 47 & $\begin{array}{l}\text { Red spot king prawn (Melicertus } \\
\text { longistylus) trawl fishery, Australia }\end{array}$ & $1988-2004$ & 0.00583 & 0.00202 & $\begin{array}{l}\text { Annual change in FP; based on O'Neill and Leigh (2007:table } 2) \\
\text { with } \ln (\mathrm{FP})=0.005831 \times \text { Year }-11.55, \mathrm{r}^{2}=0.356^{*}, \mathrm{df}=15\end{array}$ \\
\hline 48 & $\begin{array}{l}\text { North Queensland tiger prawn } \\
\text { (Penaeus esculentus) trawl fishery, } \\
\text { Australia }\end{array}$ & $1988-2004$ & 0.00715 & 0.000928 & $\begin{array}{l}\text { Annual change in FP; based on O'Neill and Leigh (2007:table } 2) \\
\text { with } \ln (\mathrm{FP})=0.007154 \times \text { Year }-14.28, \mathrm{r}^{2}=0.798^{* *}, \mathrm{df}=15\end{array}$ \\
\hline 49 & $\begin{array}{l}\text { Southern Queensland tiger prawn } \\
\text { trawl fishery, Australia }\end{array}$ & $1988-2004$ & 0.00703 & 0.00185 & $\begin{array}{l}\text { Annual change in FP; based on O'Neill and Leigh (2007:table } 2) \\
\text { with } \ln (\mathrm{FP})=0.007034 \times \text { Year }-13.98, \mathrm{r}^{2}=0.491^{* *}, \mathrm{df}=15\end{array}$ \\
\hline 50 & $\begin{array}{l}\text { Endeavour prawn trawl fishery, } \\
\text { Australia }\end{array}$ & $1988-2004$ & 0.00957 & 0.00168 & $\begin{array}{l}\text { Annual change in FP; based on O'Neill and Leigh (2007:table 2) } \\
\text { with } \ln (\mathrm{FP})=0.009573 \times \text { Year }-19.08, \mathrm{r}^{2}=0.685^{* *}, \mathrm{df}=15\end{array}$ \\
\hline 51 & $\begin{array}{l}\text { Saucer scallop (Amusium balloti) } \\
\text { trawl fishery, Queensland, } \\
\text { Australia }\end{array}$ & $1988-2004$ & 0.0049 & 0.00138 & $\begin{array}{l}\text { Annual change in FP; based on O'Neill and Leigh (2007:table 2) } \\
\text { with } \ln (\mathrm{FP})=0.004788 \times \text { Year }-9.515, \mathrm{r}^{2}=0.444^{* *}, \mathrm{df}=15\end{array}$ \\
\hline
\end{tabular}

Other estimates that were obtained from secondary data are documented (Table 1). Overall, these estimates of $C$ range from 0.0049 to $0.201 \mathrm{yr}^{-1}$, with a group of suspiciously low values $\left(0.0049-0.0245\right.$ year $\left.^{-1}\right)$ published by O'Neill et al. (2003) and O'Neill and Leigh (2007), who studied fishing power in various Australian invertebrate fisheries (see numbers 30 and $44-51$ in Table 1).
When the estimates of $C$ in Table 1 are converted to $\ln (C \%)$ and plotted against the logarithm of the number of years for which they were estimated, the result is the significantly negative relationship $(P<0.005$; Fig. 3$)$ summarized by the equation:

$$
C \%=13.8 \times Y^{-0.511}
$$


Table 2. Estimated technology coefficients of fishing vessels by vessel type (data from Fitzpatrick 1996), modified from Gelchu and Pauly (2007:table 2.5).

\begin{tabular}{lccc}
\hline \hline Vessel type & $\begin{array}{c}\text { Vessel length } \\
(\mathrm{m})\end{array}$ & \multicolumn{2}{c}{$\begin{array}{c}\text { Technology coefficient (relative } \\
\text { to 1980 = 1) }\end{array}$} \\
\cline { 3 - 4 } & & 1965 & 1995 \\
\hline Super trawler & 120 & 0.6 & 2.5 \\
Tuna seiner & 65 & N/A & 1.6 \\
Freeze trawler & 50 & 0.7 & 2.0 \\
Tuna longliner & 65 & 0.5 & 2.3 \\
Purse seiner & 45 & 0.6 & 2.0 \\
Stern trawler & 35 & 0.6 & 1.9 \\
Longliner & 35 & 0.4 & 2.8 \\
Multipurpose vessel & 25 & 0.6 & 2.5 \\
Shrimp trawler & 25 & 0.5 & 2.2 \\
Gillnetter & 15 & 0.4 & 1.5 \\
Trawler & 13 & 0.5 & 1.8 \\
Fast potter & 10 & 0.3 & 1.4 \\
Pirogue (canoe) & 10 & 0.6 & 1.3 \\
Mean ( 2 standard & & $0.53 \pm 0.23$ & 1.98 \\
deviations) & & & \pm 0.93 \\
\hline
\end{tabular}

which links $C \%$ to the duration of the period ( $Y$, in years) for which $C \%$ was estimated. The average fishing power increase was $3.4 \%$ for the average period of $15 \mathrm{yr}$ (Fig. 3). The regression relationship is not very tight, but given the heterogeneous nature of the data that went into the point estimates and of the underlying models (general linear models, chains of comparisons of successive trawler type, subjective assessments, etc.), a better fit probably cannot be expected.

Our results can be used in a practical way for a specific fishery or for global fisheries (see Anticamara et al. 2011) for which there is no other estimate of technological creep. The following equations can be used to calculate increase in effort $(E)$ or decrease in CPUE as indicators of abundance.

$$
E_{(\mathrm{t})}=E_{(\mathrm{t}=0)} \times(1+p d)^{\mathrm{t}}
$$

where $t$ is the time in years after $t=0$ and $p d$ is the percentage creep reexpressed as a decimal fraction, i.e., $C \% / 100$. The multiplier for correcting CPUE is then:

$$
\begin{aligned}
& \operatorname{Corr}_{(\mathrm{t})}=(1-p d)^{\mathrm{t}} \\
& \operatorname{CPUE}_{\text {Corr(t) }}=\operatorname{CPUE}_{(\mathrm{t})} \times \operatorname{Corr}_{(\mathrm{t})}
\end{aligned}
$$

where the first value of CPUE is treated as $t=0$, which leads to $\operatorname{Corr}_{(\mathrm{t}=0)}=1$.

These equations are now part of the CMSY method (a Monte Carlo method for estimating maximum sustainable yield) as originally presented by Froese et al. (2017) but whose implementation code is now modified to include an option for accommodating technological creep in the CPUE data that can be used as constraints (see http://oceanrep.geomar.de/33076/).

\section{DISCUSSION}

Eq. 1 provides estimates of $C \%$ values of $1.3 \%$ for $100 \mathrm{yr}, 1.9 \%$ for $50 \mathrm{yr}, 4.3 \%$ for $10 \mathrm{yr}$, and $6.1 \%$ for $5 \mathrm{yr}$. No pattern could be identified for the data (Table 1) that would have allowed for specific fisheries (pelagic vs. demersal, large scale vs. small scale) to be identified (except for the low values of O'Neill and collaborators [2003, 2007]).

Our results also have a deeper societal aspect related to the rapid decline, in the Anthropocene, of global biodiversity (Butchart et al. 2010), particularly in the oceans (Worm et al. 2006). This decline is due, in large part, to the terrible efficiency of the technology that we deploy to torture what we want from soils (e.g., through fertilizers applied to irrigated monocultures) or from the oceans (e.g., by deploying thousands of trawlers, which destroy sea-floor communities). The problem is that we do not really notice this because of shifting baselines (Pauly 1995): To us, a tractor plowing a field in the 21st century looks like a tractor at the beginning of the 20th century, and a trawler plowing the sea in the 21 st century looks like a trawler at the beginning of the 20th century. However, the newer technologies are profoundly different in that they have much greater environmental impacts than do the older ones. We will be in trouble as a species if we do not account for this difference.

\section{CONCLUSION}

When analyzing time series of CPUE obtained from commercial vessels (as opposed to research vessels, whose rigging and operations are standardized and are supposed to remain similar over decades), Eqs. 2-4 can be used in the absence of any knowledge about the technological creep in a given fishery. This method also should apply to the effort used in stock assessments in surplus production modeling (Schaefer 1954), CMSY (Froese et al. 2017), or related methods.

Responses to this article can be read online at: http://www.ecologyandsociety.org/issues/responses. php/11136

\section{Acknowledgments:}

This study was supported by the Sea Around Us, a research activity of the University of British Columbia funded by several philanthropic foundations, among which are the David and Lucille Packard Foundation, Oak Foundation, and the Marisla Foundation. We thank Sebastian Villasante for inviting us to contribute to the special feature of Ecology and Society. We also thank Rainer Froese for Eqs. 2-4, which should facilitate the future use of our results.

\section{LITERATURE CITED}

Anticamara, J. A., R. Watson, A. Gelchu, and D. Pauly. 2011. Global fishing effort (1950-2010): trends, gaps, and implications. Fisheries Research 107(1-3):131-136. https://doi.org/10.1016/j. fishres.2010.10.016

Arreguín-Sánchez, F. 1996. Catchability: a key parameter for fish stock assessment. Reviews in Fish Biology and Fisheries 6 (2):221-242. https://doi.org/10.1007/BF00182344

Atmaja, S. B., and D. Nugroho. 2011. Impact of the increasing catchability coefficient of the large purse seiner to the depletion of the small pelagic fish biomass in the Java Sea. Indonesian Fisheries Research Journal 17(1):13-20. https://doi.org/10.15578/ifrj.17.1.2011.13-20 
Banks, R., S. Cunningham, W. P. Davidse, E. Lindebo, A. Reed, E. Sourisseau, and J. W. de Wilde. 2001. The impact of technological progress on fishing effort. Agricultural Economics Research Institute (LEI) Report PR.02.01. Wagenigen University, Wagenigen, The Netherlands.

Beverton, R. J. H., and S. J. Holt. 1957. On the dynamics of exploited fish populations. United Kingdom Ministry of Agriculture and Fisheries, Fisheries Investigations (Series 2) 19. Reprint 1993. Chapman and Hall, London, UK.

Brown, R. S., N. Caputi, and E. Barker. 1995. A preliminary assessment of increases in fishing power on stock assessment and fishing effort expended in the western rock lobster (Panulirus cygnus) fishery. Crustaceana 68(2):227-237. https://doi. org/10.1163/156854095X00124

Butchart, S. H. M., M. Walpole, B. Collen, A. van Strien, J. P. W. Scharlemann, R. E. A. Almond, J. E. M. Baillie, B. Bomhard, C. Brown, J. Bruno, K. E. Carpenter, G. M. Carr, J. Chanson, A. M. Chenery, J. Csirke, N. C. Davidson, F. Dentener, M. Foster, A. Galli, J. N. Galloway, P. Genovesi, R. D. Gregory, M. Hockings, V. Kapos, J.-F. Lamarque, F. Leverington, J. Loh, M. A. McGeoch, L. McRae, A. Minasyan, M. H. Morcillo, T. E. E. Oldfield, D. Pauly, S. Quader, C. Revenga, J. R. Sauer, B. Skolnik, D. Spear, D. Stanwell-Smith, S. N. Stuart, A. Symes, M. Tierney, T. D. Tyrrell, J.-C. Vié, and R. Watson. 2010. Global biodiversity: indicators of recent declines. Science 328:1164-1168. https://doi. org/10.1126/science. 1187512

Damalas, D., C. D. Maravelias, and S. Kavadas. 2014. Advances in fishing power: a study spanning 50 years. Reviews in Fisheries Science and Aquaculture 22(1):112-121. https://doi. org/10.1080/10641262.2013.839620

Eigaard, O. R., B. Thomsen, H. Hovgaard, A. Nielsen, and A. D. Rijnsdorp. 2011. Fishing power increases from technological development in the Faroe Islands longline fishery. Canadian Journal of Fisheries and Aquatic Sciences 68(11):1970-1982. https://doi.org/10.1139/f2011-103

Engelhard, G. H. 2008. One hundred and twenty years of change in fishing power of English North Sea trawlers. Pages 1-25 in A. Payne, J. Cotter, and T. Potter, editors. Advances in fisheries science: 50 years on from Beverton and Holt. Blackwell, Oxford, UK. https://doi.org/10.1002/9781444302653.ch1

Engelhard, G. H. 2016. On the need to study fishing power change: challenges and perspectives. Pages 89-101 in K. Schwerdtner Maáñez and B. Poulsen, editors. Perspectives on oceans past: a handbook of marine environmental history. Springer, Dordrecht, The Netherlands. https://doi.org/10.1007/978-94-017-7496-3 6

Fernandez, J. A., J. M. Cross, and N. Caputi. 1997. The impact of technology on fishing power in the western rock lobster (Panulirus cygnus) fishery. Pages 1605-1610 in D. A. McDonald and M. McAleer, editors. MODSIM 1997 international congress on modelling and simulation. Modelling and Simulation Society of Australia and New Zealand, Canberra, Australia. [pnline] URL: https://www.mssanz.org.au/MODSIM97/Vol\%204/Fernandez. pdf

Fitzpatrick, J. 1996. Technology and fisheries legislation. Pages 191-199 in Food and Agriculture Organization of the United Nations, editor. Precautionary approach to fisheries. Part 2: scientific papers. Prepared for the Technical Consultation on the Precautionary Approach to Capture Fisheries (Including Species Introductions), Lysekil, Sweden, 6-13 June 1995. FAO Fisheries Technical Paper 350, part 2. FAO, Rome, Italy. [online] URL: http://www.fao.org/3/w1238e/W1238E09.htm\#ch7

Froese, R., N. Demirel, G. Coro, K. M. Kleisner, and H. Winker. 2017. Estimating fisheries reference points from catch and resilience. Fish and Fisheries 18(3):506-526. https://doi. org/10.1111/faf.12190

Gascuel, D., A. Fonteneau, and E. Foucher. 1993. Analyse de l'évolution des puissances de pêche par l'analyse des cohortes: application aux senneurs exploitant l'albacore (Thunnus albacares) dans l'Atlantique Est. Aquatic Living Resources 6 (1):15-30. https://doi.org/10.1051/alr:1993002

Gelchu, A., and D. Pauly. 2007. Growth and distribution of portbased global fishing effort within countries' EEZs from 1970 to 1995. Fisheries Centre Research Reports 15(4). http://dx.doi. org/10.14288/1.0074748

Gulland, J. A. 1956. On the fishing effort in English demersal fisheries. Fishery investigations, series II, volume XX, number 5. Ministry of Agriculture and Fisheries, London, UK.

Hannesson, R., K. G. Salvanes, and D. Squires. 2008. Technological change and the tragedy of the commons: the Lofoten fishery over hundred and thirty years. NHH Department of Economics Discussion Paper 5/2008. NHH Norwegian School of Economics, Bergen, Norway. https://doi.org/10.2139/ $\underline{\text { ssrn. } 1550841}$

Hart, A. M., A. W. Thomson, and D. Murphy. 2011. Environmental influences on stock abundance and fishing power in the silver-lipped pearl oyster fishery. ICES Journal of Marine Science 68(3):444-453. https://doi.org/10.1093/icesjms/fsq166

Houghton, R. G. 1977. The fishing power of trawlers in the western English Channel between 1965 and 1968. Journal du Conseil International pour l'Exploration de la Mer 37(2):130-136. https://doi.org/10.1093/icesjms/37.2.130

Hutton, T., S. Pascoe, C. O'Brien, and B. Rackham. 2003. A comparison of technical efficiency estimates for seven English fleets in the North Sea from stochastic production frontier (SPF) and data envelopment analysis (DEA). Pages 56-70 in S. Pascoe and S. Mardle, editors. Single output measures of technical efficiency in EU fisheries. Second edition. CEMARE Report 61. Centre for the Economics and Management of Aquatic Resources, University of Portsmouth, Portsmouth, UK.

Kimura, D. K. 1981. Standardized measures of relative abundance based on modelling $\log$ (c.p.u.e.), and their application to Pacific ocean perch (Sebastes alutus). Journal du Conseil International pour l'Exploration de la Mer 39(3):211-218. https:// doi.org/10.1093/icesjms/39.3.211

Kirkley, J., P. C. J. Morrison, S. Cunningham, and J. Catanzano. 2001. Technical progress in the Sète trawl fishery, 1985-1999. Working Paper 01-001. University of California, Davis, USA. [online] URL: https://escholarship.org/uc/item/8t8670wj

Marchal, P., B. Andersen, D. Bromley, A. Iriondo, S. Mahévas, F. Quirijns, B. Rackham, M. Santurtún, N. Tien, and C. Ulrich. 2006. Improving the definition of fishing effort for important 
European fleets by accounting for the skipper effect. Canadian Journal of Fisheries and Aquatic Sciences 63(3):510-533. https:// doi.org/10.1139/f05-238

Marchal, P., J. R. Nielsen, H. Hovgård, and H. Lassen. 2001. Time changes in fishing power in the Danish cod fisheries of the Baltic Sea. ICES Journal of Marine Science 58(1):298-310. https:// doi.org/10.1006/jmsc.2000.1011

Marchal, P., C. Ulrich, K. Korsbrekke, M. Pastoors, and B. Rackham. 2002. A comparison of three indices of fishing power on some demersal fisheries of the North Sea. ICES Journal of Marine Science 59(3):604-623. https://doi.org/10.1006/jmsc.2002.1215

Morizur, Y., and N. Carn. 2000. Contribution à l'évaluation et à l'évolution de la puissances de pêche des fileyeurs français. R.INT. DRV/RH-Brest/00-11. Institut français de recherche pour l'exploitation de la mer (IFREMER), Issy-les-Moulineaux, France. [online] URL: https://archimer.ifremer.fr/doc/00000/1243/

Munro, G., and U. R. Sumaila. 2002. The impact of subsidies upon fisheries management and sustainability: the case of the North Atlantic. Fish and Fisheries 3(4):233-250. https://doi. org/10.1046/j.1467-2979.2002.00081.X

O’Neill, M. F., A. J. Courtney, C. T. Turnbull, N. M. Good, K. M. Yeomans, J. Staunton-Smith, and C. Shootingstar. 2003. Comparison of relative fishing power between different sectors of the Queensland trawl fishery, Australia. Fisheries Research 65 (1-3):309-321. https://doi.org/10.1016/j.fishres.2003.09.022

O’Neill, M. F., and G. M. Leigh. 2007. Fishing power increases continue in Queensland's east coast trawl fishery, Australia. Fisheries Research 85(1-2):84-92. https://doi.org/10.1016/j. fishres.2006.12.006

Pascoe, S., D. Tingley, and B. Cattermoul. 2003. Estimating the efficiency of UK English Channel vessels using DEA and stochastic production frontiers. Pages 22-55 in S. Pascoe and S. Mardle, editors. Single output measures of technical efficiency in $E U$ fisheries. Second edition. CEMARE Report 61. Centre for the Economics and Management of Aquatic Resources, University of Portsmouth, Portsmouth, UK.

Pauly, D. 1995. Anecdotes and the shifting baseline syndrome of fisheries. Trends in Ecology and Evolution 10(10):430. https://doi. org/10.1016/S0169-5347(00)89171-5

Pauly, D., V. Christensen, S. Guénette, T. J. Pitcher, U. R. Sumaila, C. J. Walters, R. Watson, and D. Zeller. 2002. Towards sustainability in world fisheries. Nature 418:689-695. https://doi. org/10.1038/nature01017

Pauly, D., and M. L. D. Palomares. 2010. An empirical equation to predict annual increases in fishing efficiency. Fisheries Centre Working Paper 2010-07. Fisheries Centre, University of British Columbia, Vancouver, Canada. [online] URL: http://www. seaaroundus.org/doc/Researcher+Publications/dpauly/PDF/2010/ OtherItems/AnEmpiricalEquationToPredictAnnualIncreasesInFishingEfficiency.pdf

Robins, C. M., Y.-G. Wang, and D. Die. 1998. The impact of global positioning systems and plotters on fishing power in the northern prawn fishery, Australia. Canadian Journal of Fisheries and Aquatic Sciences 55(7):1645-1651. https://doi.org/10.1139/ $\underline{\text { 998-037 }}$
Ruiz-Luna, A., M. Jacob-Cervantes, and A. Esparza-Haro. 1997. Trends in fishing indices for the thread herring fishery in northwest Mexico. Fisheries Management and Ecology 4(1):55-61. https://doi.org/10.1046/j.1365-2400.1997.00110.x

Sanders, M. J., and A. J. Morgan. 1976. Fishing power, fishing effort, density, fishing intensity and fishing mortality. Journal $d u$ Conseil International pour l'Exploration de la Mer 37(1):36-40. https://doi.org/10.1093/icesjms/37.1.36

Schaefer, M. B. 1954. Some aspects of the dynamics of populations important to the management of the commercial marine fisheries. Bulletin of the Inter-American Tropical Tuna Commission 1(2):27-56. [online] URL: https://www.iattc.org/ PDFFiles/Bulletins/_English/Vol-1-No-2-1954-SCHAEFER, \% 20MILNER $\% 20$ B. Some $\% 20$ aspects $\% 20$ of

$\% 20$ the $\% 20$ dynamics $\% 20$ of $\% 20$ populations $\% 20$ important $\% 20$ to $\%$ 20the $\% 20$ management

$\%$ of $\% 20$ the $\% 20$ commercial $\% 20$ marine $\% 20$ fisheries.pdf

Squires, D. 1994. Sources of growth in marine fishing industries. Marine Policy 18(1):5-18. https://doi.org/10.1016/0308-597X(94) 90085-X

Thorson, J. T., and J. Berkson. 2010. Multispecies estimation of Bayesian priors for catchability trends and density dependence in the US Gulf of Mexico. Canadian Journal of Aquatic Sciences 67 (6):936-954. https://doi.org/10.1139/F10-040

Thurstan, R. H., S. Brockington, and C. M. Roberts. 2010. The effects of 118 years of industrial fishing on UK bottom trawl fisheries. Nature Communications 1:15. http://dx.doi.org/10.1038/ $\underline{\text { ncomms } 1013}$

von Brandt, A. 1964. Fish catching methods of the world. Fishing News, London, UK.

Ward, P. 2008. Empirical estimates of historical variations in the catchability and fishing power of pelagic longline fishing gear. Reviews in Fish Biology and Fisheries 18(4):409-426. https://doi. org/10.1007/s11160-007-9082-6

Westrheim, S. J., and R. P. Foucher. 1985. Relative fishing power for Canadian trawlers landing Pacific cod (Gadus macrocephalus) and important shelf cohabitants from major offshore areas of western Canada, 1960-81. Canadian Journal of Fisheries and Aquatic Sciences 42(10):1614-1626. https://doi.org/10.1139/ f85-202

Worm, B., E. B. Barbier, N. Beaumont, J. E. Duffy, C. Folke, B. S. Halpern, J. B. C. Jackson, H. K. Lotze, F. Micheli, S. R. Palumbi, E. Sala, K. A. Selkoe, J. J. Stachowicz, and R. Watson. 2006. Impacts of biodiversity loss on ocean ecosystem services. Science 314(5800):787-790. https://doi.org/10.1126/science.1132294

Zhou, S., R.C. Buckworth, N. Ellis, R. A. Deng, and S. Pascoe. 2015. Getting all information out of logbooks: estimating banana prawn fishable biomass, catchability, and fishing power increase, with a focus on natural mortality. ICES Journal of Marine Science 72(1):54-61. https://doi.org/10.1093/icesjms/fsu013 